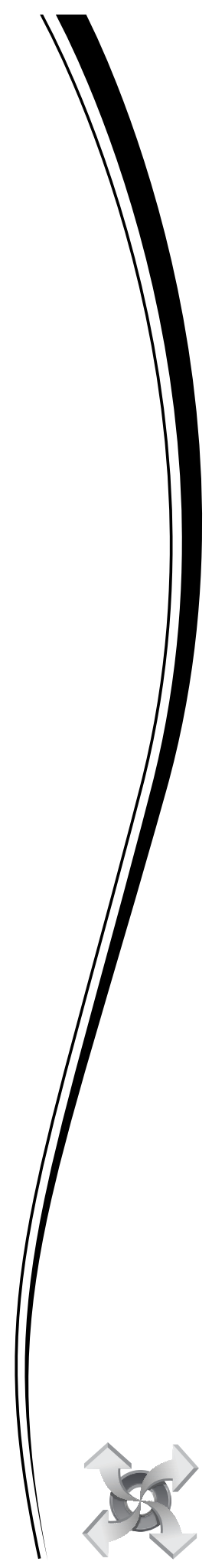

Jurnal Ekonomi, Manajemen dan Akuntansi Islam I M A NEN S I Volume 1

Nomor 1

Halaman 1-74

Malang, September 2013 ISSN 2339-1847

\title{
SO, WHAT IS SHARIA ACCOUNTING?
}

\author{
Iwan Triyuwono \\ Universitas Brawijaya, J1. MT. Haryono 165 Malang \\ Email: iwant@ub.ac.id; itriyuwono@gmail.com
}

\begin{abstract}
Abstrak. Jadi, Apa itu Akuntasi Syariah?: Penelitian ini bertujuan mengeksplorasi sifat akuntansi syariah dari sudut pandang fungsi serta tujuannya. Analisis dan sinstesis konseptual dilakukan untuk mendapatkan suatu keunikan dari akuntansi syariah. Berdasarkan perspektif khalifatullah fil ardh, fungsi dan tujuan dari akuntansi syariah melampaui kehidupan duniawi. Akuntansi syariah berfungsi sebagai instrumen doa dan zikir (pengingat Tuhan) untuk membangunkan kesadaran ketuhanan.
\end{abstract}

Abstract. So, What is Sharia Accounting?: The study attempts to explore the nature of sharia accounting in terms of its function and objective. Conceptual analysis and synthesis are conducted to arrive at a unique exhibition of sharia accounting. Based on the perspective of khalifatulllahfilardh, the function and objective of sharia accounting go beyond the worldly life. Sharia accounting functions as an instrument ofdoa (prayer) and dzikr (remembering God) for awakening God consciousness.

Keywords: sharia accounting, khalifatulllahfilardh, prayer, remembering God, God consciousness.

Modern accounting is generally understood as a means of doing business. It is even known as a language of business. It is presented as accounting information that is useful for users to make aneconomic decision. Accounting information reflects an entity's economic reality. As a reflection of an entity, accounting is thus expected to function as a map that may direct and signal users in making an economic decision.

Of course, the map generated by an accounting system depends on a worldview on how the accounting system is constructed. When a reality is ontologically perceived as physical, then accounting is designed and constructed in terms of a tangible being. Accordingly, accounting may function as a means to reflect physical reality that is finally specified in monetary terms. It is like a map that tries to portray a territory. "But, the map cannot be considered the territory simply because the map is a reflexive product of the map maker's invention" (Van Maanen 1979:520).

Accounting may also be based on a secular worldview. This view believes that accounting has no relations with religions or religious values (Gallhofer and Haslam2004; Tinker 2004; McPhailet al. 2004; Moerman 2006). It is purely worldlybusiness. There is no relation or interaction with religions. Based on this view, accounting is constructed on worldly frameworks that consequently reflect a separated reality, i.e., a separated worldly-heavenlyreality (Laughlin 1988; Booth 1993; Schweiker 1993; Parker 2001; 2002; Shearer 2002).

Among others, both materialism and secularism shapemodern accounting. Being material and secular are the main values on it. They are true values and suitable for the modern accounting. It is possible that the values are alive in a modern society, then they shape 
accounting as a cultural artefact of the society. The next step, accounting strengthens the values practiced in the society.

However, in a broader perspective, accounting is not limited to such values. It goes beyond worldly business, i.e. heavenly one.Islam, in this context, sees reality as a holistic and unified one (Gambling and Karim1986; 1991; Lewis 2001; Sulaiman and Willett 2003; Tinker 2004; Kamla 2009). There is no separation between human life and reality. Physical reality is in union with mental, spiritual, and The Absolute Reality (God). God becomes the ultimate destination. Therefore, accounting in this context is treated as an instrument to guide human beings to arrive at the ultimate destination.

In contrast, modern accounting apparently sets a physical reality as the ultimate destination. Consequently, human beings never arrive at the Ultimate Reality, because they are, via accounting, circulated and trapped in a hedonic spiral of worldly life.

The key issue of the study is to emerge an alternative accounting that may guide human beings to experience all levels of reality and finally reside in a loving hug of God peacefully. The alternative accounting is, we call it, sharia accounting. It is based on theology (Gallhofer and Haslam 2004; Tinker 2004; Mc Phailetal. 2004; Moerman 2006) of Islam.

Sharia accounting is expected to be the alternative accounting. It is normatively conceptualised based on Islamic tenets in which the ultimate goal of a Muslim life is to return to God, which in Qur'anic term is expressed in an assertion of innaalillaahiwainnaailaihiraaji-uun.

To give a simple illustration of a concept of sharia accounting, the study attempts to begin with describing the conception of human being according to Islamic viewpoint. According to Islam, human being is a vicegerent of God on earth (khalifatulliahfilardh) with a certain duty and destination. Based on the perspective of khalifatullahfilardh(Arif 1985), sharia accounting is formulated, and its function and objective are explicated.

\section{KHALIFATULLLAH FIL ARDH AS A CON- CEPT OF HUMAN BEING}

Islam declares that human being is not a simple being created by God as other beings such as animal, plant, and un-living thing. Rather, he/she is a khalifatullahfilardh, a vicegerent of God on earth. As a vicegerent, human being has been given a trust (amanah) by God, that is, to produce and disperse rahmat (wealth) for universe and people (Triyuwono 2012).

Rahmat is a holistic wealth that covers physical, mental, and spiritual wealth of human being. It is in accordance with the nature of human kind. As we know, human body comprises physical, mental, and spiritual ones (Mustofa 2004; 2011; Murphy 2006). To have a healthy body, we have to fulfil our body with all-inclusive nutrition. The best nutrition is rahmat. When we consume the rahmat properly, then we can get a fit and blessed body.

In producing the rahmat, we are allowed to compose all resources that have been dispersed by God on earth. However, the use of the resources is based on divine laws, both in the sense of verbal law (ayatqauliyah) and non-verbal law (ayatkauniyyah). This is a consequence of accepting a duty from God. As a Giver of the amanah, God has a freedom to express His will. In contrast, as human beings, we must totally obey His will.

All actions that we deliverto produce rahmat are bestowed to God as worship. Indeed, the objective of the creation of human being is actually to worship God. Simply, we can say that khalifatullahfilardh is a concept of human being that is understood as a vicegerent of God on earth who has a trust (amanah) to produce and distribute rahmat for universe and people as a way of worshipping, and returning to, God.

As a trustee of God, there is a must for us to account for all activities of worship (i.e., doing business by the way of producing and distributing rahmat) to God. To account for the activities, we need an instrument, namely"sharia accounting."It is a medium to inform God and other parties (universe and people) regarding the activities that have been already done. Ideally, the information displayed in the sharia accounting is the one that may have powerful effects on users to bear in mind the mission. Therefore, we may say that sharia accounting is an art of composing information that functions as doa (prayer) and $d z i k r$ (remembering God) to fulfil economic, mental, and spiritual needs of human being as worship to God and to awaken God consciousness.

This is a unique sort of accounting that has an expectation to liberate users of accounting from the domination of hedonic wealth. For Gallhofer and Haslam (2004), 
Tinker (2004), McPhailetal. (2004), and Moerman (2006), indeed there is a need for a liberation of accounting from a secular perspective. They suggest to make use of theology as a way of liberation and construction of new models of accounting. This study meets the suggestion by using Islamic theology to contribute a new model of accounting.

The most fundamental teaching of Islam is Tawhid (al-Faruqi 1992). It is the belief in one God. Its meaning, among others, is that human being originates from God and will return to God. There are no things, except God. There are no destinations, except God. Based on this perception, the study attempts to define a concept of sharia accounting that is perceived as a vehicle to return to God.

\section{THE ART OF COMPOSING INFORMATION}

As an instrument, sharia accounting may be understood as an art of composing information. The "art," in the perspective of neuroscience, may be recognised as an expression of human's right brain to actualise something that has power of creativity (Murphy 2006; McTaggart 2008; Newberg and Waldman 2009). Our right brain, in this context, vibrates energy to attract creative energy of God. This mechanism invites creative energy that comes to us as an inspiration.

Epistemologically, the inspiration direct us how to compose sharia accounting information. In the context of sharia accounting, a type of information is not limited to quantitative-financial information, but also qualitative-nonfinancial information. It is reasonable as sharia accounting tries to capture holistic reality that accompanies a transaction.

A transaction that is delivered by a company in point of fact is complex. It involves physical transaction and non-physical transactions. Normally, modern accounting merely recognises a physical transaction that involves an exchange of goods and services. The exchange is then measured, simplified, and expressed in monetary term. It becomes accounting information, the quantitativefinancial information. However, sharia accounting does not only recognise the physical, but also the mental and spiritual transactions. In a real transaction, say, exchanging goods and services with some money, there are mental and spiritual transactions. When a seller sells goods or services with a feeling of happiness and with a consciousness that what is he/she doing is to obey divine commandment to disperse rahmat, then we can say that the transaction involves mental realm, i.e. the feeling of happiness, and a spiritual sphere, i.e., the consciousness of delivering God's command. Of course, the mental and spiritual areas cannot be measured in monetary term. They are reported as qualitative-nonfinancial information.

Thereby, sharia accounting provides both quantitative-financial information and qualitative-nonfinancial information. They are as the results of composing two types of information. This means that sharia accounting reflects a reality that exists on a company in a comprehensive manner. By doing so, we can expect that we have a clearer map of the company. Even, the information may function as doa and dzikr.

\section{THE FIRST FUNCTION OF SHARIA AC- COUNTING: DOA AND DZIKR}

Doa and $d z i k r$ are the other uniqueness of sharia accounting. Doa is a human's request on something needed to God. It is a common practice in a religious community which is expressed in good phrase or sentence. The phrase andthe sentence are presented in sharia accounting statements ${ }^{1}$ that may function as a doa. Doa is actually the expression of mental and spiritual sphere that accompany a transaction. It is actually articulated in the form of an affirmation (a positive statement) rather than a request, for example: "we distribute the rahmat with a feeling of beneficence, mercy, peace, and brotherhood" (Triyuwono 2012: 441). The sentence does not only report the fact that management has already distributed rahmat with such feelings, but also deliver a doa. Implicitly, the sentence has a meaning of requesting God to keep maintaining that we can distribute the rahmat with the feeling of benevolence, mercy, peace, and brotherhood all the time (cf.McKernan and MacLullich 2004).

Sharia accounting statements- that consist of the Statement of Commitment on Tawhid (see Table 1), the Statement of God's Rahmat (see Table 2), and the Statement of God's Amanah (see Table 3) (Triyuwono

1 Sharia accounting utilisesSharia Accounting Statements instead of Financial Statements as we have been familiar with modern accounting. The statements consist of The Statement of Commitment on Tawhid, (2) The Statement of God's Rahmat, and (3) The Statement of God's Amanah (Triyuwono 2012: 429-47). 
Table1. The Statement of Commitment on Tawhid

\author{
In the name of God, the Most Beneficent and the Merciful \\ The Statement of Commitment on Tawhid \\ Company $\mathrm{X}$ \\ For the year ended on 31 December 20xx
}
1. We do the business based on the belief in God and sharia ethics and morality
2. We do the business as worship to God and realise our duty as vicegerent of God on earth, and
3. We manage divine resources for the interest of universe and people to return to God peacefully
Thank God! (Alhamdulillah)

Source: Triyuwono (2012: 437)

2012: 437, 441, 443) - also conveys assertions of dzikr i.e., a word or a phrase that explicitly affirms to remember God.

Some assertions, such as: "in the name of Allah the Most Beneficent and the Most Merciful (bismillaahirrahmaanirrahiim)," "thank God (Alhamdulillah)," etc., are statements of dzikr. Actually, each element of sharia accounting statements is full of dzikr. We can find, for example, in the Statement of Commitment on Tawhid which states: (1) we do the business based on the belief in God and sharia ethics and morality, (2) we do the business as worship to God and realise our duty as a vicegerent of God on earth, and (3) we manage divine resources for the interest of universe and peopleto return to God peacefully (Triyuwono 2012: 437). The statement is fully qualitative-nonfinancial information that calls for users to remember God all the time. Shortly, it invites us to remember our commitment to believe in God, to do business based on sharia and worship (ibadah), and to return to God in peace (innaalillaahiwainnaailaihiraajiuun).

Doa and $d z i k r$ are sorts of information that are conveyed by sharia accounting beyond worldly business. Most information on

Table2. The Statement of God's Rahmat

In the name of God, the Most Beneficent and the Merciful

The Statement of God's Rahmat

Company $\mathrm{X}$

For the Year ended on 31 December 20xx

1. We have utilised all resources that had given by God to generate rahmat

2. We have generated rahmat based on our feelings o f beneficence, mercy, peace, and brotherhood at the amount of:
Rahmat
Rp. $\mathrm{Xxx}$

3. We have distributed the rahmat based on our feelings of beneficence, mercy, peace, and brotherhood to:

$\begin{array}{lr}\text { Suppliers } & \mathrm{Rp.} \\ \text { Owners } & \mathrm{xxx} \\ \text { Creditors } & \mathrm{xxx} \\ \text { Management } & \mathrm{xxx} \\ \text { Employees } & \mathrm{xxx} \\ \text { Government } & \mathrm{xxx} \\ \text { Other Parties } & \mathrm{xxx} \\ \text { The Eight Asnaf } & \mathrm{xxx} \\ \text { Universe } & \mathrm{xxx}\end{array}$

4. We are responsible for the ending balance of rahmat amounting $\mathrm{Rp}$. Xxx for a better performance in the future.

Thank God! (Alhamdulillah)

Source: Triyuwono (2012: 441) 
Table 3. The Statement of God's Amanah

In the name of God, the Most Beneficent and the Merciful
The Statement of God's Amanah
Company X
31 December 20xx

Source: Triyuwono $(2012,443)$

the sharia accounting statements is positive declarations. Even, the Statement of God's Rahmat never exhibits a profit or loss account, because, it basically reports rahmat that is generated and distributed by the company to stakeholders (Triyuwono 2012: 429-47).

Users of information, physically and mentally, are free from pain and stress as a result of the doa and dzikr. Scientifically, it is explicated by Emoto (2005). Based on his experiment on water, he found that when a cup of water is given good words, then the water crystal becomes good and shiny. In contrast, when the water is labelled with bad words, then the crystal is broken and dull. Interestingly, still in the Emoto's (2005) experiment, polluted water in a lake becomes fine and sparkling when people around the lake make doa for the water. This is so, because of positive words vibrates positive energy. As we know, according to quantum physics, everything in the world is made up of energy (McTaggart 2008). Doa and dzikr attract positive energy. Theyemit positive energy that makes physical and mental bodies of users in a healthy state. Not only that, spiritually they also function as a ladder that assists the users to go through the highest consciousness, that is, God consciousness.
THE SECOND FUNCTION OF SHARIA ACCOUNTING: FULFILLING THE ECONOMIC, MENTAL, AND SPIRITUAL NEEDS OF HUMAN BEING

The information of sharia accounting (that is full of doa and dzikr) is not an imagery and a superstition. It is real and able to convey information to fulfil economic, mental, and spiritual needs of stakeholders. Sharia accounting stays on an obedience to recognise the nature (fitrah) of human being. That means that it is not ascetic. It is concerned with a harmony and a balance of human needs.

Sharia accounting informs rahmat and amanah (respectively reported in the Statement of God's Rahmat and the Statement of God's Amanah) to stakeholders. Rahmat is wealth, i.e., sharia value-added, produced and distributed to stakeholders that relates to economic, mental, and spiritual needs, and so the amanah(trust). Amanah, in essence, is something that has been entrusted by God to human being.

Accompanying the economic information, mental-oriented information is also presented. The information is related to any feelings that are inherent in a company's economic transactions such as beneficence, mercy, peace, and brotherhood. The information supplies the mental needs. For ex- 
ample, the account of "we have made rahmat with feelings of beneficence, mercy, peace, and brotherhood amounting to Rp. xxx" delivers stakeholders' mental need (Triyuwono 2012: 429-47). The information activates a stakeholder's neural system to present such feelings that in turn motivates him/her to act with the feelings (Murphy 2006; McTaggart 2008; Newberg and Waldman 2009).

It also happens to spiritual-oriented information. With a same pattern (Newberg and Waldman 2009), the information fulfils a spiritual need of stakeholders. The example of the information is "we acknowledge that all resources belong to God" or "we manage the resources honestly as amanah from God for the sake of universe and people." Indeed, it is the spiritual-oriented information.

The three types of human need are united altogether. They are three in one. The economic need cannot be separated from the mental and spiritual ones. The mental need cannot be detached from the economic and spiritual ones, and the spiritual need cannot be disengaged from the economic and mental ones.

\section{THE FIRST OBJECTIVE OF SHARIA AC- COUNTING: WORSHIPPING GOD}

Having had the functions, now we come to the objectives of sharia accounting. The first objective is to worship God. It means that, firstly, all actions that we do to fulfil economic, mental, and spiritual needs are bestowed to God as worship, and secondly, sharia accounting is an instrumentto account for the actions to God.

Firstly, as a vicegerent of God on earthwho has accepted a trust (amanah) from God, we have a consciousness that all activities done for actualising the trust are recognised as worship. Day-to-day operational activities are the acts of worship. Secondly, reporting a transaction has a meaning that we remember what has been already done (and what has not been done yet) to universe and people through the transaction. This is, in a horizontal relationship, the accountability to universe and people as a consequence of accepting the divine trust, i.e., to produce and distribute rahmat to universe and people. In addition, it vertically also covers accountability to God as the reflection of the trust.

We find, in this context, three-sided accountability, i.e., accountability to people, accountability to universe, and accountability to God as the ultimate accountability.
They are in unity. They cannot be separated to each other. God is the centre and the final destination of all human actions through worship.

\section{The Second Objective of Sharia Account- ing: Awakening Human's God Conscious- ness}

The second objective of sharia accounting is to awaken human's God consciousness. God consciousness is the highest consciousness of human being. It is a sort of consciousness that basically we feel that we are in unity with God. Under this consciousness, we are all the time in a sound connection with God. Our mind, talk, and action are under the direction of God. Our ego has already gone, and the God now is present. The only One who exists forever, within us and outside us (Newberg and Waldman 2009).

The connection actually does not only happen to God, but also to universe and people. All are in One. There is nothing outside of the One. All are covered by the One. Let us contemplate the following poem, "The My Oneness:"

\section{(Ke)Satu(an)Ku}

\section{Sesungguhnya Aku hanya Satu}

Mengapa kau katakan Aku punya sembilan puluh sembilan nama? Bukankah Aku ini hanya Satu dan Tak Terbatas? Qulhuwa Allahu Ahad!

Mengapa kau katakan besar dan kecil? Bukankah yang ada itu hanya Aku, Yang MahaBesar? Allaahu Akbar!

Mengapa kau katakan Aku suci dan hambaKu najis? Bukankah Aku adalah Yang Maha Suci? Semua bagian dari DiriKu adalah suci dan semua ciptaanKu adalah suci Subhana Allah!

Mengapa kau katakan rezekiKu terbatas? Bukankah Aku 'tlah limpahkan rezeki tanpa henti? Fabiayyiaalaairabbikumaatukadzdzibaan

Mengapa kau tak berterima kasih atas semua karuniaKu? Bukankah Aku 'tlah mengajarimu 'tuk bersyukur? Alhamdulillah!

Mengapa kau katakan dirimu hamba Tuhan? Bukankah yang ada itu hanya Aku? Allahu Ahad! 
Mengapa kau katakan Aku jauh dan terpisah? Bukankah Aku lebih dekat dari urat lehermu dan 'tlah menyatu denganmu? Al-Muhith!

Mengapa kau katakan iblis itu membangkang? Bukankah ia 'tlahpatuh pada perintahKu 'tuk membangkang? AlMalikul Mulk!

Mengapa kau tuhankan agama dan syari'ahmu? Bukankah Aku ini adalah Tuhanmu? Laailaahailla Allah!

Mengapa kau begitu congkak dan lupa asal-usulmu? Bukankah engkau berasal dari Aku dan 'kan kembali padaKu? Innaalillaahiwainnaailaihiraajiuun!

Kembalilah padaKu, hai manusia!

Sesungguhnya,

Aku mencintai dirimu

Aku mencintai semua diriKu

Aku mencintaiKu, karena

Akulah ar-Rahmaan, ar-Rahiim

Semuanya adalah Aku, Ana!

Ana!

Ana!

Ana!

Ana al-Haq!

Malang, 15 November 2012/1 Muharram 1434

IwanTriyuwono

In essence, the poem tells us the oneness of God, the very basic tenet of Islam. It is also the reason of why the ultimate objective of sharia accounting is to return to God through a ceaseless effort of awakening human's God consciousness.

There are three ways to awaken God consciousness, i.e., constructing sharia accounting based on the oneness of God, stepping through an accountability ladder, and using neuro-linguistic programming (NLP) (Anonymous 2012). Firstly, understanding the nature of human being is very important, because, the understanding becomes a basis for constructing sharia accounting (Arif 1985; al-Faruqi 1992). As we described above, we see human being as khalifatullahfilardh. It brings to us a consequence to totally obey God's law in designing and constructing sharia accounting. Epistemologically, the con- struction starts, and ends, with the belief in the Oneness of God (Tawhid).Consequently, the accounting generated by the epistemology will always direct users to think and take a course of actions in accordance with the belief. Let us take the first element of sharia accounting statements as an example, i.e., The Statement of Commitment on Tawhid (see Table 1). The statement starts with God. It declares that we do the business based on the belief in one God that consequently the business, as a divine duty and worship, is undertaken on the light of sharia ethics and morality. Then, the statement ends up with God, by affirming that the business is done for the interest of universe and people for returning to God. This is the concept of innaalillaahiwainnaailaihiraajiuun, everything comes from, and returns to, God.

Secondly, awakening God consciousness may be illustrated as going upstairs by making use of an accountability ladder. The lowest step of the ladder is the accountability to universe, the middle is the accountability to people, and the highest is the accountability to God. Starting with the lowest, users are invited to unite their feeling with universe. Then the feeling may at the same time grow well to emphatically connect with other people. And, finally, users come to a consciousness to be one with God. The simple illustration gives us an understanding that accounting has an ultimate objective, that is, God. Again, God is the centre of the accounting.

Thirdly, through words, phrases, and sentences, sharia accounting ignites a bright light to stimulate the present of God consciousness. Indeed, a language in the perspective of neuroscience has a powerful influence on human neural system(Bolstad 2005; 2006; 2008; Murphy 2006; McTaggart 2008; Newberg and Waldman 2009; Anonymous 2012). Good words, phrases, and sentences stimulate neural system to think, to feel, and to act positively. They attract positive energy (Davis 2008; Oswald 2008) that covers the environment of the users in which they live. Then the environment becomes full of positive energy, the divine energy.

Acknowledging that the good language has positive energy, we can use the language as a programme to direct users of shariaaccounting to a certain direction. Under neuroscience, it is known as neuro-linguistic programming (NLP) (Anonymous 2012; Bolstad 2005; 2006; 2008). We can make use of 
neuro-linguistic programming for sharia accounting to install a programme to awaken users' God consciousness. The programme is planted in the sharia accounting statements. The wording programme is full of magical words that may arouse the users' God consciousness.

This is a sort of accounting that attempts to emancipate human beings from the prison of a worldly life to a broader and a more meaningful life. It is done by transforming the orientation of accounting to a right centre, that is, God. Accordingly, the accounting becomes a vehicle that starts from, and returns to, God. It does not stop at the middle of a spiritual journey, but at the end of the journey.

\section{Concluding Remarks}

LaailaahaillaAllah (there is no god, but God) is a declaration of Tawhid. Laailaaha (there is no god) is a negation for any things that are not gods. Theymay be money, business, position, hedonic life, and other pseudo-gods. They are not viable to be recognised as God, hence, they must be negated. Money, business, position, and other hedonic life are necessary for human life, but not for a final objective. They are just vehicles that are needed by us to go to, and arrive at, the final destination, that is, God. This is a statement of liberation, the liberation from anything other than God. Accounting, in this context, is liberated from dominations of worldly epistemology, assumption, paradigm, and destination.

However, after having a liberation, there should be a real guidance to tie human being or accounting to a true objective. In other words, there should be a balance between a negation and an acceptance. The first statement of the tawhidic declaration (laailaaha, there is no god) is a negation, the second statement (illaAllah, but God) is a confirmation, that is, an acceptance that there is God. Both the negation and the acceptance are in one. There is no separation.

Accounting, in this study, is emancipated from pseudo-gods that then fastened by the Real God. In so doing, it commits totally to the will of God and totally submits itself to the law of God. Sharia accounting is the example of this. We have it as a sort of accounting that has already proclaimed LaailaahaillaAllah. That is a reason of why sharia accounting is declared as an art of composing information that functions as doa (prayer) and $d z i k r$ (remembering God) to fulfil economic, mental, and spiritual needs of human being as worship to God and to awaken God consciousness.

\section{REFERENCES}

Al-Faruqi, I.R. 1992. Al-Tawhid: Its Implications for Thought and Life. Herndon: The International Institute of Islamic Thought.

Anonymous. 2012. What is NLP?http:// www.nlpu.com/whatnlp.htm (accessed on 15 November 2012).

Arif, M. 1985. Toward the shari'ah paradigm of Islamic economics: The beginning of a scientific revolution. The American Journal of Islamic Social Sciences, 2 (1), pp. 79-99.

Bolstad, Richard. 2005. Research on neurolinguistic programming. http://www. transformations.net.nz/trancescript/ research-on-nlp.html

Bolstad, Richard. 2006. NLP in purchasing. http://www. Transformations.net.nz/ trancescript/sales.html.

Bolstad, Richard. 2008. Healing neurology with NLP. http:/ / www.transformations. net.nz/trancescript/nlp-brain-healing. html

Booth, P. 1993. "Accounting in churches: a research framework and agenda". Accounting, Auditing \& Accountability Journal, Vol. 6 No. 4. pp 37-67.

Davis, D. 2008. The law of attraction in action. New York: A Perigee Book.

Emoto, M. 2005. The true power of water. New York: Atria Books.

Gallhofer, S. and J. Haslam. 2004. "Accounting and liberation theology: Some insights for the project of emancipatory accounting". Accounting, Auditing \& Accountability Journal. Vol. 17. No. 3, pp 382-407.

Gambling, T. and R. A. A. Karim. 1986. "Islam and 'social accounting". Journal of Business Finance \&Accounting, 13 (1), pp. 39-50.

Gambling, T. and R. A. A. Karim. 1991. Business and Accounting Ethics in Islam. London: Mansell.

Kamla, R. 2009. "Critical insights into contemporary Islamic accounting". Critical Perspectives on Accounting, 20, pp. 921-932.

Laughlin, R. 1988. "Accounting in its social context: an analysis of the accounting systems in the Church of England". 
Accounting, Auditing \& Accountability Journal, Vol. 1 No. 2, pp 19-42.

Lewis, M.K. 2001."Islam and accounting". Accounting Forum, Vol. 25. No. 2, pp. 103-127.

McKernan, J.F. and K.K. MacLullich. 2004. "Accounting, love and justice". Accounting, Auditing \& Accountability Journal, Vol. 17. No. 3, pp. 327-360.

McPhail, K., T. Gorringe, and R. Gray. 2004. "Accounting and theology, an introduction: Initiating a dialogue between immediacy and eternity". Accounting, Auditing \& Accountability Journal. Vol. 17 No. 3, pp. 320-326.

McTaggart, L. 2008. The intention of experiment. London: Harper Element.

Moerman, L. 2006. "People as prophets: liberation theology as a radical perspective on accounting”. Accounting, Auditing \& Accountability Journal.Vol. 19. No. 2: 169-185.

Murphy, J. 2006. The Power of Your Subsconscious Mind. London: Pocket Books.

Mustofa, A. 2004. Untuk Apa Berpuasa: Scientific Fasting. Surabaya: Padma Press.

Mustofa, A. 2011 Energi Dzikir Alam Bawah Sadar. Surabaya: Padma Press.

Newberg, A. and M.R. Waldman. 2009. How God changes your brain. New York: Ballantine Books.

Oswald, Y. 2008. Every word has power: switch on your language and turn on your life. New York: Atria Books.
Parker, L. 2001."Reactive planning in a Christian bureaucracy". Management Accounting Research.Vol. 12 No. 3, pp 321-56.

Parker, L. 2002."Budgetary incrementalism in a Christian bureaucracy". Management Accounting Research. Vol. 13 No. 1, pp 71-100.

Schweiker, W. 1993. Accounting for ourselves: accounting practice and the discourse of ethics. Accounting, Organizations and Society. Vol. 18 No. 2/3: 231-52.

Shearer, T. 2002."Ethics of accountability: from the for-itself to the for-the-other". Accounting, Organizations and Society. Vol. 27 No. 6, pp 541-73.

Sulaiman, M. and R. Willett. 2003. Using the Hofstede-Gray framework to argue normatively for an extension of Islamic Corporate Reports. Malaysian Accounting Review, Vol 2 (1).

Tinker, T. 2004. "The Enlightenment and its discontents: antinomies of Christianity, Islam and the calculative sciences". Accounting, Auditing, and Accountability Journal, Vol. 17, No. 3, pp. 442-475.

Triyuwono, I. 2012. Perspektif, Metodologi, danTeoriAkuntansiSyari'ah. Jakarta: RajaGrafindoPersada.

Van Maanen, J. 1979. "Reclaiming qualitative methods for organisational research: a preface". Administrative Science Quarterly.Vol. 24. No. 4, pp. 520-526. 